\section{Portuguese archives and libraries: a century of preservation and conservation practices for the control of biodeterioration}

\section{Arquivos e bibliotecas em Portugal: práticas de conservação e preservação para o controlo da biodeterioração ao longo de um século}

\author{
CONCEIÇÃO \\ CASANOVA $^{1,2 *}$ (1) \\ ANA CATARINA \\ PINHEIRO $^{3}$ (1) \\ 1. Departamento de Conservação \\ e Restauro, Faculdade de \\ Ciências e Tecnologia, \\ Universidade Nova de Lisboa, \\ Caparica, Portugal \\ 2. LAQV - REQUIMTE, \\ Faculdade de Ciências e \\ Tecnologia, Universidade Nova \\ de Lisboa, Caparica, Portugal \\ 3. Laboratório HERCULES - \\ Herança Cultural, Estudos e \\ Salvaguarda, Universidade de \\ Évora, Évora, Portugal. \\ *mccasanova@fct.unl.pt
}

\section{KEYWORDS}

Biodeterioration

Preventive conservation

Archives

Libraries

Contamination

Sustainability

\title{
Resumo
}

A biodeterioração tem sido um assunto central para Bibliotecas e Arquivos. Ao longo do tempo, diferentes medidas de conservação preventiva e curativa foram adotadas para combater a biodeterioração nas instituições Portuguesas, mas o problema persiste. São revistas as diferentes metodologias usadas para prevenir a biodeterioração no cenário português e comparadas com as tendências internacionais. Focam-se as teorias e práticas da conservação de documentos gráficos, tendo em conta a sua evolução e é, ainda, estabelecido um paralelismo entre o mundo dos coleccionadores e a esfera dos arquivos ou bibliotecas. A gestão da biodeterioração tem-se mantido como preocupação central, nomeadamente entre bibliotecários e arquivistas, dos primeiros a implementar políticas de preservação. Apesar da reconhecida importância da preservação, é vital fomentar a sua compreensão ao nível da tomada de decisão. A implementação de estratégias de conservação preventiva continua a ser insatisfatória apesar dos actuais problemas de sustentabilidade e dos perigos no manuseamento de documentação contaminada.

\section{PALAVRAS-CHAVE}

Biodeterioração

Conservação preventiva

Arquivos

Bibliotecas

Contaminação

Sustentabilidade 


\section{Introduction}

Biodeterioration, and measures to halt it, have been central issues for libraries and archives for a long time. These settings comprise mostly paper-based objects exposed to a wide range of biological agents. The main components of paper are organic materials, such as cellulose fibres and sizing materials. Other frequent materials in libraries and archives are skin-based substances (i.e. parchment and leather), natural textile fibres (i.e. linen and cotton), and natural adhesives (i.e. animal glues, vegetable gums and starch), mainly found in bookbindings but also on paper sheets. All these materials are a basic source of nutrition for living organisms such as insects and micro-organisms [1]. These materials are biodegradable, that is, they degrade as a result of the action of micro-organisms or enzymes [2] and they are bioreceptive, being easily colonized by biodeteriogens [3]. Therefore, they are susceptible to biodeterioration, which is defined as the alteration in a material caused by the vital activity of biodeteriogens [4]. The intensity of deterioration depends mainly on the material composition of the object, environment conditions and the organisms' behaviour. Their action can affect not only the aesthetic appearance of objects, but also their chemical composition and physical and mechanical properties, resulting in inestimable material loss [6]. Insects can despoil, damage and even destroy objects, leaving detritus and dirt, and causing missing areas and loss of information. According to some authors, insects are the most numerous, resilient and persistent of all the agents of deterioration [7]. They have been recognised as one of the chief causes of deterioration in objects, libraries and archive structures and the damage they induce can often be found in entire collections or buildings [1]. Furthermore, the presence of micro-organisms and insects can result in debris and food for other highly destructive pests, such as rodents.

Micro-organisms, namely fungus, easily affect paper due to its hygroscopic capacity and composition [4]. Fungi grow easily when temperature and water availability is high (around $25-30^{\circ} \mathrm{C}$ and 70-75\% RH or higher) and the bioreceptivity of the substrate and its physical-chemical properties are compatible with the needs of the colonizer [8]. Their metabolic activity on cellulose and even noncellulosic materials present in paper is very high [8]. The enzymes produced and the organic acids excreted during the digestion process cause paper disintegration, mostly by the cellulose macromolecule hydrolysis, and results in the loss of its mechanical strength and the general loss of information [4]. Besides the weakness and decomposition of paper, fungus action usually results in very unpleasant staining caused by the production of coloured metabolites, which have a strong aesthetic impact on objects. Foxing spots, a descriptive term for scattered roundish stains of reddish or yellowish-brown colour found in paper or other fibre-based materials [12], are a common example. Usually an age-related process of deterioration, foxing is still under discussion and many causes for its formation have been suggested, including several abiotic processes [12] or growth of micro-organisms [13].

This fact raises an aesthetic concern, shared not only by libraries and archives but also by graphic art collectors and bibliophiles, as demonstrated in restoration manuals [14] and other technical literature [16]. As will be explained further (Early curative conservation praxis versus preventive conservation strategies section), this also uncovers important theories and practices of paper conservation and the evolution of concepts applied to paper heritage conservation [18]. Another important aspect is the health question, since many species of micro-organisms are pathogenic and toxic and recognized as allergenic triggers able to provoke respiratory diseases [8]. Thus, from the late nineteenth century to the end of the twentieth century different preventive conservation strategies and curative conservation praxis were implemented for the control of biodeterioration in paper objects and collections.

In Portuguese institutions, although preventive conservation appears to have been on the agenda for a long time, a prevalence of curative measures through chemical control is evident, resulting in serious damage to objects and causing public health problems in renowned institutions. In fact, the chemical substances traditionally used to prevent biodeterioration processes and to control pests are very toxic, affecting the environment and people's health, and often contributing to material alteration and deterioration of cultural heritage [6]. Nevertheless, it seems that cultural heritage Portuguese managers are not aware of the seriousness of this safety issue. On the other hand, the biodeterioration problem remains unsolved, although currently, several research centres are addressing these questions. In the last decade, studies were carried out in the field of cultural heritage and materials degradation by research units from various Portuguese universities. A few examples are the Transdisciplinary Research Centre "Culture, Space and Memory" - CITCEM, from University of Porto; the research unit Glass and Ceramics for the Arts - VICARTE and the Research Centre of Excellence in Green Chemistry - LAQV Requimte from Universidade NOVA de Lisboa; the Centre for Functional Ecology from Coimbra University; the HERCULES Centre of University of Évora and the Research Centre in Science and Technology of the Arts - CITAR plus the Centre of Biotechnology - CBQF, from Universidade Católica Portuguesa. Fields such as preventive conservation, risk assessment, pest control, archives biodeterioration, identification of different micro-organisms, microbial diversity, molecular biology, biotechnology, use of safe biocides, fungus stain cleaning and removal have been targeted by these research centres but the application of the new findings in cultural heritage institutional environments has been insubstantial. 
This may result from insufficient knowledge transfer between research units and institutional environments, as well as inappropriate choices and policies on the part of managers. It is known that in times of economic downturn, maintenance is often the first area to be affected; storage areas are neglected or given less priority than readers' areas or high-profile projects with greater visibility [1]. Instead of creating infrastructures for preventive conservation such as continuous programmes for cleaning and hygiene, often viewed as menial tasks that can be done by unskilled personnel, larger investments are made in more conspicuous initiatives with more public visibility. Furthermore, in many places and institutions around the world resources allocated for conservation are diminishing [20]. So, despite the serious problem of materials contamination with traditional methods of biodeterioration control, the increasingly strong voices calling for the implementation of sustainable methods that consider cultural heritage, final users and the environment, as well as the proved costeffectiveness of preventive conservation, it is difficult to convince decision-makers of its importance in relation to other institutional expenditures.

This reality requires serious reflection supported by a historical review of the main practices in dealing with the biodeterioration problems at national institutions (section Biodeterioration and pest control: management strategies), so as to identify a clear trajectory and to discuss the factors that contributed to the present situation in Portuguese institutions. Information about biodeterioration and how pesticides, fungicides and fumigants were applied to archive and library materials is important to fully understand historical treatments and methods of care, but also for a better perception of chemical alterations and current health hazards posed by contaminated items with chemical residues. There are surely strong parallels with the cultural heritage institutional situation of other countries with similar economic paths. Thus, we believe other institutions or actors can benefit from the analysis of the Portuguese case-study, hereby described and presented.

\section{Early curative conservation praxis versus preventive conservation strategies}

\section{The restoration manuals approach}

Textbooks and manuals on restoration emerged in the nineteenth century in par with collectors' manuals [21] and art catalogues when auction houses were gaining popularity [22]. They were basically published for collectors and focused on procedures used in the treatment of paintings and works of art on paper and rare books, thus enabling us to trace the sequence of events that led to the emergence of the conservation practices used in graphic documents [18]. During the nineteenth century and first half of the twentieth century, this process was seen as a means of restoring works of art to their "pristine state", following the aesthetic standards of this period [18]. From a collector's point of view, the importance ascribed to the appearance of an object resulted in the application of rather invasive methods. In paper works, this practice was facilitated by the availability in the market of chemicals used in bleaching [23], which involved the direct use of dangerous and unstable chemicals. This is seen today as an improper and unethical approach, but at the time ethical concerns were secondary to the principles of "mimetic restoration". In paper objects, this was achieved essentially by two means: cleaning and bleaching stains to restore the original whiteness; perfect re-integrations to match new and old papers, making the restoration as invisible as possible [19]. Despite some variations in the procedures, different manuals from this period show that the removal of stains and perfect reintegration were the ultimate goals of restoration. The most extensive restoration manual portraying this ideal in works of art on paper was authored by Bonnardot and dates from the mid-nineteenth century. Based on his own experience, the author placed great emphasis on cleaning as a way to improve the appearance of the artwork. Bonnardot devoted five complete chapters to this topic [18]. For fungal stains, considered by the author as one of the most difficult to remove, he recommended the use of bleaching, starting with a weaker formula and increasing it according to the intensity of the stain, but taking into consideration the paper quality and its fragility [14]. Several other authors addressed this issue in their publications, i.e. Ris-Paquot [24], Gunn [26], Beaufort [27] and Lucanus [28], as well as the Portuguese artist and writer Manuel de Macedo [15].

Although less complete in their explanations, they all recommended the same type of methods and products and followed identical principles. Macedo's unique Portuguese manual of this kind followed closely the textbooks of RisPaquot and Bonnardot, reflecting the French influence in the Portuguese cultural scene. His main concern was also to restore the antique paper to its original appearance. Bleaching was one of the procedures used to clean paper, followed by toning down to confer a uniform aged tone. Other procedures included reintegration with a paper as similar as possible to the original [18]. To in-fill the missing areas from heavy insect attack, again Macedo recommended the use of paper pulp following Bonnardot's formula, to mask all anomalies and create, as much as possible, invisible joints [15].

Although all these invasive treatments envisaged a "mimetic intervention" that obeyed an aesthetic ideal, the authors also mentioned some preservation requirements. Bonnardot cautions the reader for the importance of humidity and temperature control. He defines, as the general rule, a need for books and prints to be kept in dry rooms with low heat, "since moisture causes mould in the papers and excess heat promotes the development of worms, sometimes deposited in glues and skins" (authors' 
translation) [14]. Macedo also recommends avoiding temperature and humidity, and draws attention to the importance of ventilation. He advises the reader about the choice of good materials for the folders and the boxing process, since some materials react strongly to humidity [15].

Textbooks like Bonnardot's manual still constituted a reference in the twentieth century [29] but various changes occurred in the first half of that century. In the midtwentieth century, the engraver-restorer Schweidler, while continuing to defend the idea of an invisible restoration of art on paper, directed his textbook to the expert technician instead of the amateur collector, which suggests the emergence of a new professional: the paper conservator [18, 30]. On the other hand, the manual of Morgana (1932) [29] and of Plenderleith (1937) [31] written in the 1930s mentions new products that had meanwhile invaded the market, such as synthetic products, and new equipment like the sterilization chamber, which were to play an important role in disasters such as the floods which occurred in Florence in 1966 [29]. Plenderleith's book also outlined a new methodology for the conservation of works of art on paper similar to that used in museum objects. The author begins by describing the composition of different materials and defines the main causes of their deterioration, including the biologic action. He dedicates a chapter to fungi and characterizes types of staining and deterioration, explaining the role of environmental conditions and lack of ventilation. A further section is dedicated to aspects like storage conditions and exhibition facilities, inspired by the work that was being carried out at the British Museum by Alexander Scott (18531947), founder of the scientific laboratory [20]. Regarding the praxis of conservation, the author emphasizes the need for a full diagnosis and introduces a new mandatory step: the use of a sterilization fumigation chamber to be applied prior to traditional procedures such as bleaching, which was by then considered accessory [31]. But in terms of remedial conservation and restoration procedures, such as cleaning with strong bleaching agents, repairing, and in-fill, there was no innovation. In fact, Plenderleith follows the philosophy and methods of intervention mentioned by previous authors $[18,31]$. So, for the first half of the twentieth century, the art collectors' world still maintained the ideal of "mimetic intervention" and valued the pristine appearance of the artwork after restoration.

\section{Technical bibliography for archives and libraries}

Faced with a growing concern for the physical and chemical stability of paper objects, librarians and archivists were the ones who led the way to the first conferences on conservation and restoration of documents. The first was the Internationale Konferenz zur Rrhaltung uns Ausbesserung alter Handschrifen, held in St. Gall, 1889, followed by an archivist's meeting, 1899, Dresden, and the Librarians International Conference, 1900, Paris, [32]. These professionals were also the first to implement ethical principles of restoration carried out on this type of material, considering their historical nature and probative value, namely archive documents. For example, one of the main concerns of Sir Henry Cole (1808-1882), who since 1840 was in charge of the Public Record Office, in London, was to ensure that the restoration process did not alter the integrity and the legal value of documents [22]. These professionals revealed great concern and in-depth knowledge of preventive conservation, including early pest control. The subject was widely emphasized in their professional compendia, such as the Manual on Archive Administration [33] published in the early twentieth century. This publication followed closely the ideas of Sir Henry Cole and dedicates a full chapter to the "enemies of the manuscripts" and their management [33]. Other examples are the Manuel pratique $d u$ bibliothècaire [34] and the Bibliothéconomie [17]. The latter, written in mid-twentieth century, included a full chapter about conservation in which the author claims that worms and humidity are one of the most common and difficult problems to solve in an archive. He also points out some solutions, such as improving air circulation and using a methodology developed years prior, that involved the use of essential oils and camphor [17]. In the Manuel pratique $d u$ bibliothècaire, Maire dedicated a section to the fundamentals of conservation and elaborates on the biggest enemies of books: insects, dust deposits, humidity and temperature. He advises against deterioration processes and recommends adopting good practices such as the ventilation of rooms, cleaning and using good storage materials and procedures [34]. This author goes even further and addresses safety and disaster planning, starting with the actual construction of a building and protection against external threats [34].

In Portugal, the management of bibliographic and archival heritage has involved, for a long time, its physical and material care, with particular emphasis on preventive conservation measures. This is directly associated to the conditions of the buildings and storage facilities, as well as the presence of pests, which were considered one of the main causes of deterioration in the literature of archives and libraries during the nineteenth and twentieth centuries. A small group of intellectuals, usually associated with the humanities, i.e. librarians, archivists, curators and scholars, who were also often themselves collectors of rare books and artworks and held administrative positions in cultural heritage institutions, were the first to turn their attention to the issue of preventive conservation [35]. Several authors defined the ideal conditions of the buildings that housed archives: they had to be resistant to fire, dry, and free of pests. João Pedro Ribeiro (1758-1839) was one of the first scholars to address the issue in his publication: Observações historicas e criticas [16]. His work was based on a survey on the state of Portuguese archives, a study carried out upon request of Queen D. Maria I of Portugal for the Science Academy of Lisbon (Academia 
das Ciências de Lisboa), which had been founded under her patronage. According to Ribeiro, the place where the archives were stored, did not comply with recommended international management methodologies and did not offer safe conditions. The main problems detected were: lack of adequate human resources, lack of an accurate and detailed inventory, improper storage conditions (i.e. high levels of humidity and no ventilation), and absence of adequate means to ensure that books and documents were free of "animals and insects, which everyone knows how much they can destroy (...)" (authors' translation) [16]. To deal with this pest problem, Ribeiro recommended "neatness, cleaning and supervision" (authors' translation) [30], procedures suggested by any current Integrated Pest Management (IPM) policy. During the nineteenth century, several authors reinforced this stance. For example, Fr. Francisco de São Luís Saraiva (1766-1845), supervisor of the National Archives (ANTT, Arquivos Nacionais - Torre do Tombo) between 1834 and 1836, wrote a manuscript where he defined three main dangers: fire, humidity, and insects. He recommended "sweeping the house frequently, dusting the cabinets, and from time to time leafing through the books to shake off the dust" (authors' translation) [36]. The author also talks about storage practices (i.e. the use of protective folders glued with a paste containing "vinegar" to repel pests, shelves of good quality wood that should also be oiled to prevent insect attacks) following the recommendations in international textbooks written by the field professionals. At the turn of the nineteenth century, the historian Pedro Azevedo, who held various positions in renowned institutions in Portugal, such as the ANTT and the National Library (BNP, Biblioteca Nacional de Portugal), wrote a publication about the Portuguese context entitled Meios de defesa dos archivos. In his work the author explains the effects of humidity on paper and the relationship between air volume, temperature and water vapour (i.e. absolute and relative humidity), advocating the use of a hygrometer. He associated humidity to the harmful action of micro-organisms, alerted his readers about the problem of insects, and recommended the use of metal shelves [37].

From the late nineteenth century until the end of twentieth century the situation of the BNP became a major concern, particularly since the extinction of the religious orders in 1834 that resulted in many of their works being increasingly integrated into this public library. The library was relocated in 1836 to the damp Convent of S. Francisco and in 1844 the Library's director, José Feliciano Noronha (1810-1879) sent a report to the Minister of the Republic, Costa Cabral (1803-1889) drawing attention to the "most terrible enemies" present in this public library: dust, humidity and insects. He concluded that "whatever the point of view is, everything in the Convent of S. Francisco is unsuitable for its current intended purpose" (authors' translation) [38]. But it wasn't until the early twentieth century that the situation was made public with an event called "A sad but necessary exhibition" (i.e. Uma exposição triste mas necessária) on April 26, 1920. This exhibition was organized by a group of intellectuals that included librarians and archivists, founders of the Library Friends Society (Sociedade dos Amigos das Bibliotecas). Having proven the importance of their professional class, they soon expanded it to the Archives [39]. In fact, by the late nineteenth century, librarians and archivists were already a skilled professional class. In 1887, under the sponsorship of the Archives and Erudite Libraries Inspection (Inspeç̧ão das Bibliotecas Eruditas e Arquivos), a higher education course was created for archivists and librarians. The course included the discipline of Bibliology and encompassed the care and preventive conservation of collections [40]. In 1918, the course was reorganized, and the BNP was put in charge of coordinating a seminar on the "hygiene of bibliographic species" [41]. It is important to note that the discipline was taught by a natural scientist, reinforcing the importance given to biological questions and showing that interdisciplinary teamwork was taking its first steps. Problems, especially with insect control, justified the involvement of experts who were not confined to the humanities, and naturalists began to assume a position in the field. The phenomenon was well underway across Europe in areas such as paintings and museum objects but, in Portugal, given the poor condition of archives and libraries, graphic documents seem to have taken precedence over other cultural heritage sectors.

Later, with the creation of an official professional body of librarians and archivists in the twentieth century, and the founding of a professional association (1973), a forum of discussion was initiated through regular national conferences and the participation of Portuguese professionals in international events. In the early 1970s Lisbon hosted the IIC's International Congress, "Conservation of Paintings and Graphic Arts", and at the end of that decade, a Working Week in the Conservation of Graphic Documents was held, congregating, for the first time in Portugal, librarians and archivists, scholars, curators, cultural heritage managers, chemists, biologists and conservators. In this forum, preservation issues such as environmental conditions, disaster planning, and biologic causes of deterioration were central topics of discussion. The main points stressed by the participants were: urgency in establishing a preventive conservation policy founded on a national plan to upgrade existing facilities and build new ones; the need to define priorities based on a systematic survey of the conservation condition of collections; the creation of a research centre for the study of conservation problems and causes of deterioration, and to help establish rules. However, despite the awareness of specialists in Portugal, lack of support from the political sphere and decision-makers will persevere, and the research centre was never created [35]. 


\section{Biodeterioration and pest control: management strategies}

\section{Policies and surveys}

Since the mid-nineteenth century, different approaches for biodeterioration control and pest eradication have been employed in Portugal's National archives and Library. These methods are reviewed and presented alphabetically in Table 1. Fungicide, pesticide and fumigant use by the collections' management staff is documented chronologically, characterizing the most important trends in library and archive management during the late nineteenth and twentieth centuries in Portugal.

Historical information was collected mainly from archival written sources (i.e. survey records, products acquisition; management records) combined with oral information for recent periods, in four representative institutions: the BNP and the ANTT (as the main reference institutions in Portugal), the latter including the management of the eighteen district archives; the Overseas Historical Archive (AHU, Arquivo Histórico Ultramarino), one of the first institutions to face serious pest problems due to the origin of the archives (i.e. records from the ex-colonies in tropical regions); and the Calouste Gulbenkian Foundation (FCG, Fundação Calouste Gulbenkian), a private institution with an important role in the field due to the floods of 1967 in the greater Lisbon (a year after the floods in Florence), which seriously affected its collections. In fact, a laboratory for specialized conservation and restoration was created specifically to treat the affected collections, and official training for paper conservators was initiated. Until then, the only paper conservation workshop that ran on a regular basis, was the one set up in the AHU by a bookbinder trained in Rome at the Institute of Book Pathology (Instituto di Patologia del Libro) to deal with the aforementioned serious biodeterioration problems (Figure 1).

The great concern with biodeterioration, particularly pest control, led management staff to carry out several surveys in public institutions. In 1946, the already mentioned Archives and Erudite Libraries Inspection endorsed an inquiry on the conditions of the inventory, the building (environmental conditions), measures for the prevention of fire and theft, and other preservation conditions such as handling procedures, dust and hygiene methods and, of course, biodeterioration control [40]. New surveys were conducted in 1957 and 1968, the last totally focused on the problem of insects [39]. The inspector intended to set up a department for the study of the sanitary conditions of libraries and archives where a policy against biodeterioration could be developed [42]. The intention was to conduct a rigorous survey of the prevailing pest species, to analyse their habitat and to investigate how they acted in different environments, as well as to make a statistical assessment of how the attacks occurred [43]. However, the results of this research are not known. An attempt to establish a national policy for chemical pest control in archives and libraries was undertaken again in the 1980 s in the Department of Libraries and Archives of the Portuguese Institute of Cultural Heritage (IPPC, Instituto Português do Património Cultural) [44] but at the time many alternative methods for pest control where already being set up at an international level. A last survey of the

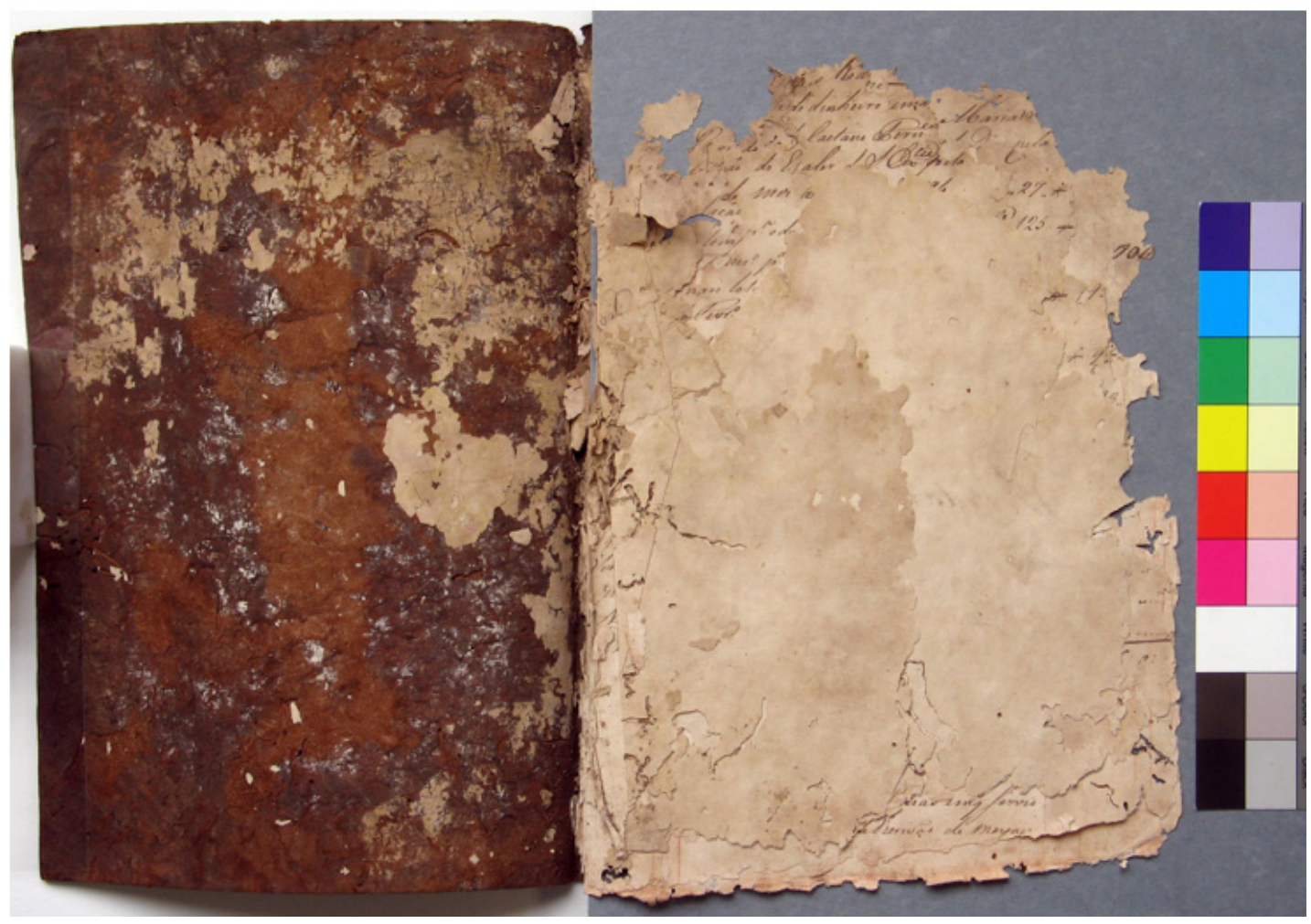

Figure 1. AHU, Governo Geral da Índia, Junta da Fazenda - 17th century book showing heavy biodeterioration caused not only by woodworms but also by microorganisms. This particular book was under extremely high humidity and its support has suffered intense acidification. 


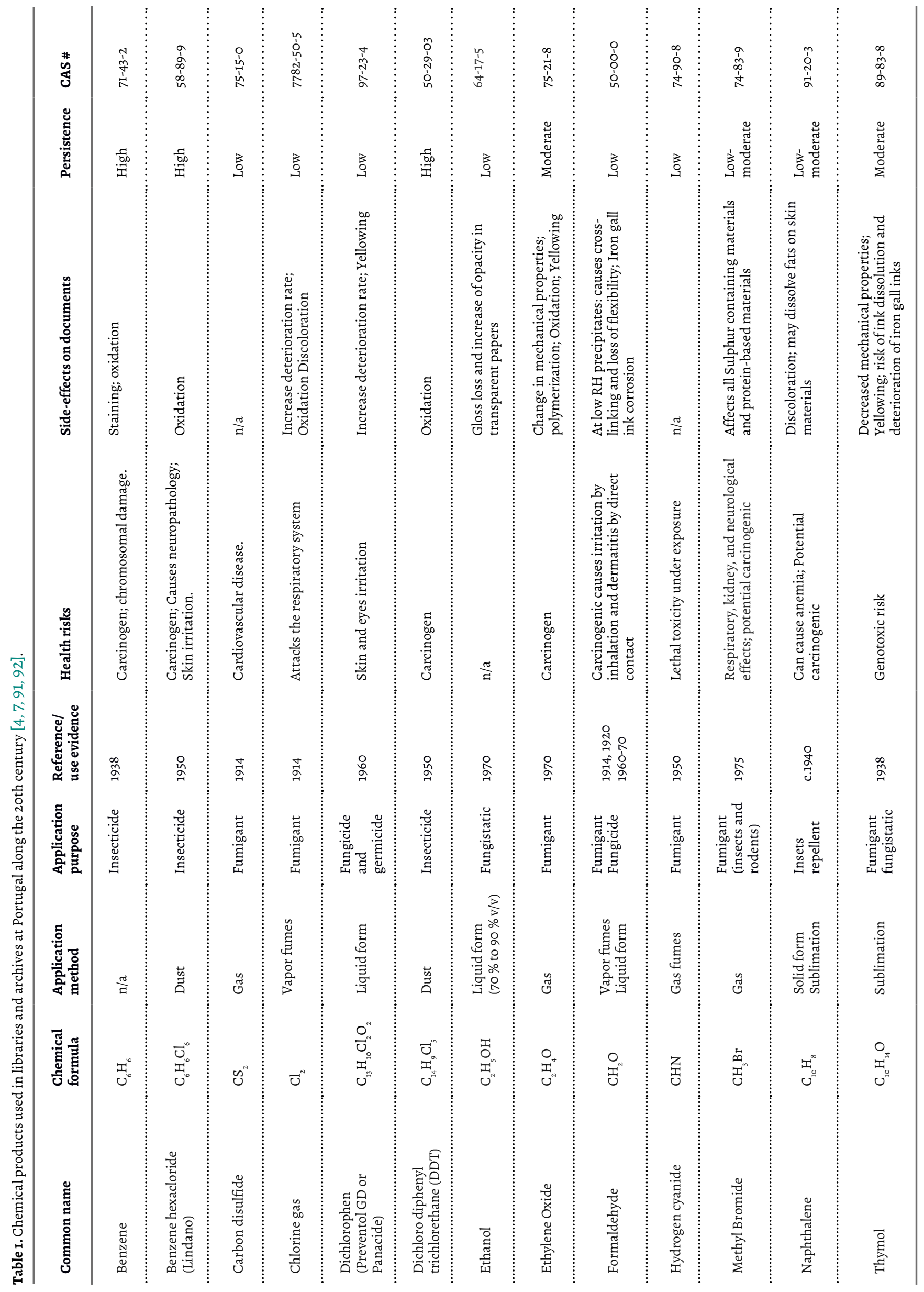


national archives was carried out in the early nineties by the National Archives Institute (IPA, Instituto dos Arquivos Nacionais) [45]. The main target of this survey was the evaluation of preservation and conservation conditions at district archives and it was divided into three key topics: (i) general condition of the archives, from buildings to storage facilities; (ii) major deterioration processes observed in the documentation; and (iii) different solutions and treatments frequently carried out. A preservation course for collection managers was organized by the IPA prior to the survey and all eighteen district archives in the country completed it. Biodeterioration was identified as one of the primary problems faced by archive management teams resulting in regular use of chemical products. The main pests found are presented in Table 2.

During the survey, very poor environmental conditions were observed, and usually, the unsuitability of installations included infrastructure problems. The relative humidity registered was as high as $80 \%$ to $90 \%$ with oscillations of $20 \%$ in a single day, and many problems were found in the buildings, such as poor construction materials used, lack of insulation, deficient plumbing and electrical power, etc. Archives used fumigation products on a regular basis (once to twice a year); after the fumigation treatment, storage areas were ventilated, but no monitoring of the air quality was done [45]. In short, no significant changes seemed to have occurred throughout the twentieth century. A preservation policy was finally defined for the National Archives starting with the building itself, which resulted in the PARAM programme (Programa de Apoio à Rede de Arquivos Municipais
- Support Programme for the Municipal Archives Network), initiated in 1998, for the improvement and requalification of archives, where IPM strategies were implemented.

Although preventive conservation recommendations have circulated among archives and libraries for a long time and there have been many preventive conservation recommendations throughout the twentieth century, we realize that the main methods employed in biodeterioration control until the end of the twentieth century involved the use of chemical products, i.e. poisons and pesticides (Table 1). Different methods for disinfestation as a way of exterminating insects and rodents, and disinfection or sterilisation to control and eliminate microorganisms were implemented based on the use of toxic products.

Cost and lack of immediate and obvious alternatives seem to have conditioned the choice of pest control techniques. Human health and safety concerns were sometimes mentioned, but in the early days of the twentieth century, information about the long-term side-effects of the use of chemical products was not available and the public health authorities allowed their use [35]. In the late nineties, this became a concern and gradually some changes were made thanks to both increased consciousness and new facilities. But due to lack of regular funding and steady investment this problem still prevails.

\section{Chemical options for biodeterioration and pest management}

As mentioned above, the curative treatments recommended by Macedo, following Bonnardot and other European

Table 2. List of most common insects affecting books found in libraries and archives in Portugal [45, 87, 93].

\begin{tabular}{|c|c|c|c|c|c|}
\hline Order & Family & Genus & Species & $\begin{array}{l}\text { Common } \\
\text { name }\end{array}$ & Affected Materials \\
\hline \multirow[t]{2}{*}{ Blattodea } & Ectobiidae & Blattella & $\begin{array}{l}\text { Blattella germanica } \\
\text { (Linnaeus) }\end{array}$ & $\begin{array}{l}\text { Small } \\
\text { cockroach }\end{array}$ & $\begin{array}{l}\text { Affects mostly binding materials but } \\
\text { can also bite the paper leaving an } \\
\text { irregular contour on the edges. }\end{array}$ \\
\hline & Rhinotermitidae & Reticulitermes & $\begin{array}{l}\text { Reticulitermes } \\
\text { lucifugus (Rossi) }\end{array}$ & Termite & $\begin{array}{l}\text { When it reaches collections it can } \\
\text { severely affect all kind of materials. }\end{array}$ \\
\hline \multirow[t]{3}{*}{ Coleoptera } & Ptinidae & Anobiidae & $\begin{array}{l}\text { Anobium punctatum } \\
\text { (De Geer ) }\end{array}$ & $\begin{array}{l}\text { Furniture } \\
\text { beetle }\end{array}$ & $\begin{array}{l}\text { Affects wood boards and paper causing } \\
\text { large perfect circular holes and tunnels. }\end{array}$ \\
\hline & & Stegobium & $\begin{array}{l}\text { Stegobium paniceum } \\
\text { (Linnaeus) }\end{array}$ & $\begin{array}{l}\text { Drugstore } \\
\text { beetle }\end{array}$ & $\begin{array}{l}\text { Affects wood boards and paper causing } \\
\text { also perfect circular holes and tunnels, } \\
\text { usually smaller than Anobium. }\end{array}$ \\
\hline & Dermestidae & Dermestes & $\begin{array}{l}\text { Dermestes maculatus } \\
\text { (De Geer) }\end{array}$ & Leather beetle & $\begin{array}{l}\text { Affects parchment and leather } \\
\text { materials in books. }\end{array}$ \\
\hline Lepidoptera & Tineidae & Tineola & $\begin{array}{l}\text { Tineola bisselliella } \\
\text { (Hummel) }\end{array}$ & clothes moth & $\begin{array}{l}\text { Affects mainly cloth and silk bindings } \\
\text { and endpapers. }\end{array}$ \\
\hline Psocoptera & Liposcelididae & $\begin{array}{l}\text { Liposcelis } \\
\text { (Motschulsky) }\end{array}$ & n/a. & booklice & $\begin{array}{l}\text { Affects mainly glue or paste of } \\
\text { bookbindings and glazed paper. }\end{array}$ \\
\hline Zygentoma & Lepismatidae & Lepisma & $\begin{array}{l}\text { Lepisma saccharina } \\
\text { (Linnaeus) }\end{array}$ & Silverfish & $\begin{array}{l}\text { Affects paper leaving a grazing effect } \\
\text { on the surface; it can bite through the } \\
\text { paper leaving an irregular contour on } \\
\text { the edges. }\end{array}$ \\
\hline
\end{tabular}


authors, also had a disinfection function. Cleaning with chlorine and other bleaching agents for the removal of stains, namely fungal stains, was done not only for aesthetic purposes but also to prevent biodeterioration from spreading. Another chemical substance recommended by early Portuguese bibliography of archives and libraries (Technical bibliography for archives and libraries section) was the use of essential oils [36] again following European references, i.e. Constantin's manual and his preservation measures [34]. The Portuguese author does not specify the type of oil to be used, but he recommends its application on wooden bookshelves to repel insects [36]. The fumigation of spaces, introducing chemical substances such as a toxic gas in a confined area was mentioned for the first time in a nineteenth century document written by João Campanha, head of the Royal Chemical Laboratory of Casa da Moeda [39]. Campanha recommends the use of heated sulfuric acid over salt to form hydrogen chloride gas, and closing the space for $24 \mathrm{~h}$, although it is not clear how this exothermic reaction could occur safely. However, the use of chemical products to halt biodeterioration is, in fact, a twentiethcentury trend. The Book Disinfection \& Sanitation Station (Posto de Saneamento e Desinfestação de Livros) was established by $1914[35,46]$ under the aegis of the aforementioned Archives and Erudite Libraries Inspection. This public entity recommended the use of gaseous fumigants such as chlorine gas (a common disinfectant also used for paper bleaching by oxidation reactions) and carbon disulphide (used at the time as an insecticide for the fumigation of food) [47] in a fumigation cabinet or box; and formaldehyde in a fumigation chamber [39]. Further evidence of the use of formaldehyde is mentioned in the cleaning, sterilization and disinfestation of the archive collections of the S. José Hospital in Lisbon [48]. In libraries and archives environment, this carbon compound was advocated for a long period. Maire's nineteenth-century manual already mentioned it, and in 1971 the British Museum pamphlet on biocides for archival and library materials still recommended formaldehyde [49]. Nevertheless, as early as the 1960s, Gallo mentions the difficulty in eliminating its residues [50]. It is recognised that formaldehyde has strong microbicidal properties, but also low penetration capacity for library and archival collections [51], and thus is not always effective. Formaldehyde has also been reported to cause several deterioration problems to archival and libraries materials such as cross-linking of cellulose, loss of flexibility in paper and skins, and corrosion of iron gall inks [4]. In terms of public health, it causes irritation to the eyes and mucous membranes, and in 1978 it was declared to be a carcinogen [4].

In the late thirties, we also find a reference to the use of thymol (5-methyl-2-isopropyl 1-phenol) and benzene (aromatic hydrocarbon) which, according to Sampaio, served "to kill and repel insects and to clean the books" (author's translation) [53]. As mentioned above, Plenderleith's manual also recommends the use of thymol as a topical fungicide in the sterilization fumigation cabinet on a regular basis [31] and in the eighties, it was virtually the only fumigant used in archives in the United Kingdom [54]. Several studies advocated its qualities as a fungicide and bactericide, but others reported its ineffectiveness in tackling paper fungi infections $[4,54]$. Secondary effects were also reported by different authors after the treatment of papers with thymol, such as decrease of mechanical resistance and folding endurance [55] discolouration and yellowing of paper [58] and the general degradation of paper, binders, glues and inks $[58,60]$. Regarding toxicity, some authors suggest it has a destructive capacity to alter genetic material [61].

In the 1950 s the use of chemical materials directly on, or next to documents to avoid insects spreading was advised and documented. This is the case of naphthalene (solid polycyclic hydrocarbon), a product recommended in the late nineteenth century for cultural heritage objects [62]; and insecticides of the organochlorine group, such as DDT (Dichloro-Diphenyl-Trichloroethane) at $20 \%$, and lindane (gamma-hexachlorocyclohexane). Following instructions from the National Civil Engineering Laboratory (LNEC, Laboratório Nacional de Engenharia Civil), the last two were applied in the AHU where, as mentioned before, a serious problem with biodeterioration was felt [35]. DDT was also used in the BNP, where some contaminated documents still have residues and exhibit strongly oxidised and deteriorated cellulose (Figure 2).

DDT became popular as an insecticide after the Second World War, and it began to be produced industrially around 1945. It was used in agriculture and later in the cultural heritage sector. However, in the sixties, voices were raised against its frequent use. Here we must refer to the early work of Carson [63] about the deleterious effects of this pesticide in the environment. In fact, this pesticide requires safe handling to avoid being absorbed by the skin and through inhalation [64]. Also, it is a very persistent substance that results in bioaccumulation and biomagnification along trophic chains, leading to the contamination of both top predators and humans [65].

By the mid-twentieth century, fumigation with hydrogen cyanide gas was encouraged by fumigation companies to treat the storage areas of the Overseas Historical Archive (AHU). According to the records, this was also in use in the National Archives and Library [35]. This is an extremely poisonous and flammable material, so the AHU management team asked for advice. They consulted the Institute of Agriculture (ISA, Instituto Superior de Agronomia) about insect characterization and LNEC for information about the product. The Portuguese National Health Service was also asked for authorization to apply the substance. LNEC and ISA advised against its use, but the Health Services authorized the procedure. So, despite the dangers and risk of toxicity to neighbours, staff and users, the treatment was performed on a regular basis for several years. The alternative suggested by LNEC was either 


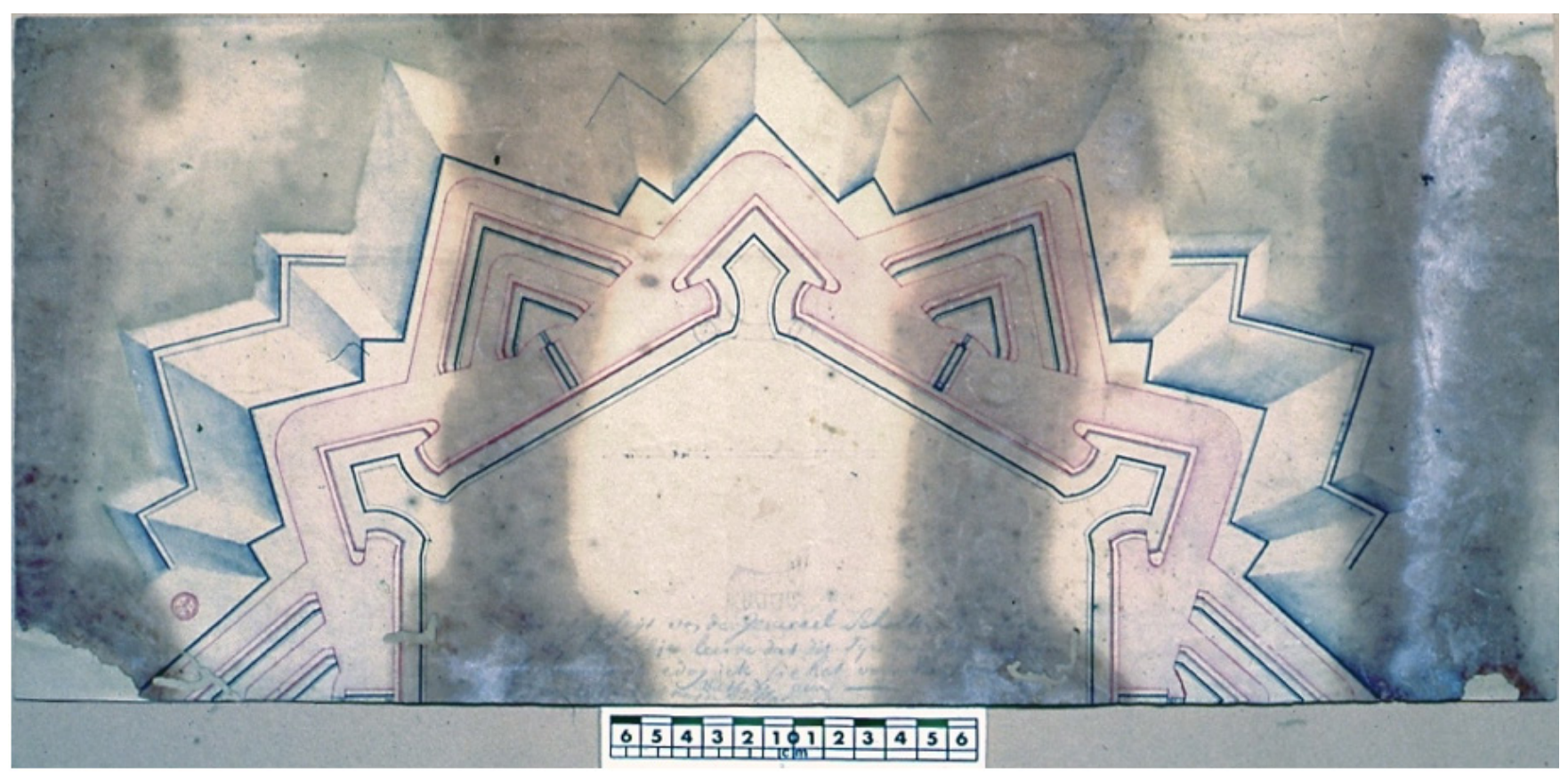

Figure 2. BNP, Iconography collections, 17th-century architectural drawing revealing deposits of DDT powder, according to BNP information.

ethylene oxide (EtO) or methyl bromide in a fumigation chamber. The AHU did apply methyl bromide in the late seventies, and again in the nineties, but not in a fumigation chamber. In fact, the Archive applied it as a fumigation gas in open storage areas, when alternative solutions were already being studied all over the world. Its hazardous effect on sulphur-containing materials, such as photographic collections and most contemporary papers (i.e. sulphate and sulphite process papers) [66], as well as leather book bindings and any protein-based material, was soon recognised, as it causes serious damage to the protein structure [67]. Finally, methyl bromide was banned from the market when it was identified as noxious and detrimental to the ozone layer. Methyl bromide was also used in a fumigation vacuum chamber by FCG, after the Lisbon floods of 1967.

Ethylene oxide was adopted by the BNP, where a fumigation vacuum chamber was installed in the seventies in its new building. Ethylene oxide was developed in 1859 but it was in the following century that became widely used in museums, libraries and archives [68]. Due to its high capacity of penetration at room temperature, it has excellent microbicidal properties as well as very good insect elimination qualities that made it a very popular disinfestation and sterilization method [4]. But some authors refer that after treatment paper documents become more susceptible to microbial attack [54,69]. In the eighties, new studies brought to light its harmful effects both on materials and on human health [70] and, more recently, EtO has been declared a carcinogenic, mutagenic, genotoxic and neurological hazard $[4,68]$. Usually mixed with $\mathrm{CO}_{2}$ to reduce flammability and explosiveness, it remains on paper and on protein-based materials for long periods where it reacts with cellulose causing loss of strength. In paper containing chlorine, it reacts forming ethylene chlorohydrin or glycol ethylene, toxic products that remain on the paper, affecting users $[4,71]$. For circa three decades the fumigation chamber was in use in the BNP but the chemical persistence on documents was finally considered a serious health hazard and it closed in the nineties. In the last decade of the twentieth century, the National Archives moved to a new building where a classic fumigation chamber was installed but due to a succession of difficulties, the equipment was never operating. Nevertheless, ANTT faced a big challenge: they moved to the new, more comfortable building, but without taking any precautions. They occupied new storage rooms with infested items and the insects (Stegobium paniceum) developed twice as fast than in the previous cold environment of the old stone building.

Meanwhile, conservation labs were set up in the major institutions in Portugal and new chemicals were introduced for curative treatments on biodeteriorated items. This was the case of the original conservation laboratories of graphic documents in the AHU and FCG established in the 1960s, where Dichlorophen (4-cloro-2-[(5-chloro-2-hydroxyphenyl) methyl] phenol), whose commercial name is Preventol GD or Panacide, was used for cleaning infected objects over several decades, namely documents affected by the Lisbon floods, where fungi quickly developed. These chemical substances are usually applied in organic solvents and have a strong effect on yeast and filamentous fungus [4, 72]. But an increase in the paper deterioration rate after its use was observed [73], as well as the fact that it could cause health problems, such as eye and skin irritation [72]. In 2009 it stopped being sold in the European Union free market as a biocide [4].

It is known that in the AHU conservation workshops a fumigation box was improvised for systematic use in 
documents prior to their full conservation treatment. The chemical product applied was carbon disulphide, recommended since 1914 by the Portuguese authorities through the Book Disinfection \& Sanitation Station and in use at the Vatican Archives laboratory in Rome.

In the 1980s, a conservation-restoration laboratory was set up in the BNP, and in the early nineties, the conservation services of the ANTT were established. In both locations, a membrane-active microbicide, ethanol at $70 \%$, was adopted to treat documents affected by fungi. In fact, some authors stated that aqueous solutions from $50 \%$ to $80 \%(\mathrm{v} / \mathrm{v})$ are more effective than pure alcohols, with the maximum efficiency at $70 \%$ [74]. Recently, Sequeira showed that a 70 $\%$ ethanol solution displayed fungicidal properties on four out of five tested fungal species (sporulating fungi) and proved that none of the ethanol solutions tested (from 5 to $100 \%)$ promoted conidia germination but rather delayed or inhibited it entirely, depending on concentration and duration of contact [76]. Ethanol is mainly applied by spraying or by immersion in a bath, which is reported to be a more effective treatment [74], although it can cause opacity and deformation to documents, as well as dissolution of certain types of inks [75].

\section{Non-chemical option for biodeterioration and pest management}

Regular hygiene was recommended from very early on, as an important way of controlling biodeterioration. In Portugal, like in other countries, archivists and librarians have always advocated regular cleaning of collections and preservation measures, starting with storage areas and buildings. According to Pinniger, $90 \%$ of successful pest control depends on good hygiene $[1,77]$. Pests develop with unsuitable environmental conditions, but they also thrive on dirt and rubbish which provides them with shelter, as well as food.

The enforcement of an Integrated Pest Management in museums, libraries and archives was imported from the agricultural sphere. Although this management program includes pesticides, the better and recommended approach is to choose the method of lowest risk for people, collections and the environment [78].

As mentioned, cleaning is probably the most important part of any IPM Program [77]. FCG was one of the first institutions to develop a cleaning programme for the collections. This institution also used freezing facilities right after the Lisbon floods of 1967. The freezing process was done as an intermediate method to prevent microorganism growth until further conservation treatments were done, but it is not totally innocuous. Some changes in the characteristics of the most fragile paper substrate, such as chemical reactions induced by an increased concentration of solutes; and physical damage caused by the formation of ice crystals, can occur during the freezing process. Furthermore, some micro-organisms' cells may still be viable after normal conditions arise [76]. However, freezing does present itself as a non-toxic alternative, namely for insect control. As explained by Strang, the problems around pesticide use, particularly environmental impact, increased awareness and lead to studies on thermal efficacy to reduce pest action on cultural heritage; although this area of study "can still benefit from efforts to obtain efficacy data for species, aimed towards minimizing treatment times or increasing confidence around undocumented species" [80].

In 1997, the National archives were the first institutions to adapt the traditional vacuum chamber to a low oxygen chamber. This modified atmosphere method provides an anoxia environment for the pests by total exclusion of oxygen and its substitution for nitrogen or carbon dioxide. The latter is more efficient than nitrogen, namely for fungus growth control [81] but nitrogen atmospheres do not interfere with the $\mathrm{pH}$ of paper like carbon dioxide sometimes does. When the relative humidity is also controlled, very good results can be achieved, not only for most insects but also for micro-organism control [76, 82]. As reported by several authors it is environmentally friendly, very effective and safe for sensitive objects [82]. The drastic situation of pests' invasion at the new storage areas experienced at ANTT resulted in the setting up of an IPM programme to prevent it, based on monitoring with traps and building maintenance, and avoiding the use of chemical products. At the end of the century, in 1998, BNP also changed the circuit of the EtO vacuum chamber into an anoxia nitrogen system and runs a regular cleaning programme for documents in storage areas. However, in these institutions due to financial constraints, the various steps were taken slowly.

\section{Sustainability and management of pests and biodeterioration}

The topic of sustainability within Biodeterioration and Pest Management must fulfil two different needs: the conditions needed to sustain a program making it long-lasting, effective and safe for objects and users; and the choices made to tackle this issue on the face of our current environment needs.

The effectiveness of any management option is dependent on the support given by the administration. Success stories in tackling the problem of pests under any IPM program have been partially awarded to its centralisation on one staff member in a dedicated job post [85]. This is not the case for the large majority (or even all) of Portuguese institutions where all the IPM related tasks (assessment, implementation, monitoring, evaluation, reporting, communication and compliance to current norms and legislations) are additional to other daily activities. Another important aspect to be considered is the lack of awareness that decision-makers reveal as some seem to be totally oblivious to the harmful effects of the past and present use of chemical products. Contaminated materials 
require great precaution to be safely accessible, though how this can be done is still a demanding field of study. And if all of these were not enough already, climate change demands even more attention. Not only must the last-resort chemical options be sustainable and respectful of the environment as preventive measures - such as temperature and relative humidity control - must also comply with energy-saving goals [78]. Also, the expected global temperature rise means the world will experience higher temperatures and microorganisms and pests we are now acquainted with may become more aggressive or disappear and give rise to other different species with different behaviours and demanding different management approaches [86]. In fact, at Portugal, the struggle caused by the spreading to the whole country of some species, such as the subterranean termite (Reticulitermes lucifugus) affecting several historic buildings [87]; and the Silverfish (Lepisma saccharina) [88] affecting mostly textile and paper collections, is becoming a big problem that it seems we are not exactly prepared for.

As mentioned in the previous section, the displacement of atmospheric oxygen is a well-established method included in the European Standard EN 16790:2016 Conservation of Cultural Heritage - Integrated pest management for protection of cultural heritage (CSN EN 16790). Portugal has done some investments in this type of treatment. It plays a vital role in eliminating insect infestation on cultural heritage objects, movable or immovable and represents one of the best options available, both on efficacy and health or environmental concerns. However, the EU included nitrogen in Annex I of the Regulation (EU) No 528/2012 of the European Parliament and of the Council of 22 May 2012 [89] which concerns the market availability of biocidal products. With the extension of mandatory registration of on-site generated nitrogen from September 2017 by the biocidal products regulation $\mathrm{EU}$ 528/2012 these facilities can no longer be operated and there is a real danger, if this position is not reverted, that this could lead to the resurgence of all those dangerous (for both health and heritage) chemicals used in the past. This was the main argument used by the ICOM and ICOMOS joined statement (supported also by the Network of European Museum Organizations) requesting the repeal of the classification of nitrogen as a biocide so that it can remain as the safest option now available to Cultural Heritage preservation across the European Union (ICOM-ICOMOS, 2012) [90]. To build the case to revert this situation, a public consultation on derogations for the protection of cultural heritage was in place at the European Chemicals Agency website until January 18th. At the moment of submission of this article, the final decision is still pending.

\section{Discussion and final conclusions}

During the nineteenth century, and throughout the twentieth century, there was a general concern with biodeterioration caused by micro-organisms and insects, and ways to mitigate them. This preoccupation is evident in restoration manuals, archives and libraries' technical bibliographies and in the records of important institutions operating in the field of archives and libraries.

The evolution of intervention principles and methods that have guided the conservation of graphic documents lies between two very distinct worlds, requiring a multifaceted reflection ranging from the analysis of the procedures adopted in the conservation/restoration of art on paper, to treatments applied in archives and libraries, including common treatment methods used in books and documents. On the application of chemical products both Bonnardot and Macedo resorted to the chemical means available in the market, such as bleaching and disinfection agents, with a single purpose: the perfect, unnoticeable intervention. Nevertheless, preventive measures to maintain the restored/ conserved items in good conditions are also mentioned by the several authors, gaining momentum with Plenderleith.

A strong tonic on prevention has always been present on the methodologies to avoid and solve the biodeterioration problem. Among us, like abroad, archivists and librarians were a well-organized class and played a prominent role in the preservation policies of the graphic cultural heritage, during the nineteenth and twentieth centuries being the ones who first referred to the conservation problems affecting graphic documents and trying, early on, to define conditions for their preservation. Archives and library compendiums, were, apart from the technical aspects of archival organization and management, also at the centre of conservation issues and the discussions about the conditions for safeguarding archival cultural heritage. Until the mid-twentieth century, Portuguese authors always refer to the ideal conditions of a building and identify pest control as a powerful tool to master in archives and libraries. The various surveys carried out, first at the Archives and Erudite Libraries Inspection and later at the IPPC and the IPA, speak to the awareness in these professionals. Among us, they led the way for an interdisciplinary team by involving natural scientists in their education (i.e. libraries and archives professional course and seminar), setting up a discussion forum through the organization of conferences (i.e. Working Week in the Conservation of Graphic Documents) and asking for advice from other specialists (i.e. LNEC, ISA).

However, less than ideal situations affected paradigmatic institutions: the first location of the BNP in an unsuitable building; the regular arrival to the AHU of infested material from the colonial administration; the floods that affected the FCG collections; the transferral of the national archives to a new building without the previous disinfestation and quarantine of its records, are several of the disasters and singular events in the history of Portuguese National Archives and National Library of Portugal that contributed to an increase in professional awareness and the development of preservation initiatives. The tenacity with 
which the early defenders of preservation tried to show the positive impact of preventive conservation in collection's management was followed by a more definitive integration of preservation means into the institution's practices. Nonetheless, the twentieth century history of archives and libraries saw very modest preservation achievements, and experienced, rather, a prevalence of easier options that were also the least effective ones in the long term. These entailed the indiscriminate use of chemical products. Again, this was the trend all over Europe, but in Portugal these options showed circa a decade of delay, undoubtedly due to lack of financial resources, as well as bad management decisions, particularly in the public archives and Library. The heavy use of toxic chemical products documented in the archival sources, and oral information gathered from interviews with older workers and retired staff is quite impressive, especially if we attend to the current knowledge in the new millennium about the effects of these products and the imperative need of sustainable managing at a large scale. Many institutions with archive and library collections probably have similar histories of fungicide, pesticide and fumigant use. But the quantity of chemicals products which were used at Portuguese institutions, leaving inorganic and organic residues, such as dangerous insecticides like naphthalene and DDT among others, with a high persistence, are certainly troublesome. The historical summary presented here provides a basis for further investigations into the potential health hazards for users in reading rooms and individuals entrusted with the care of archives and libraries. The goal of such research is mainly to detect and establish the levels of contamination and its relation to health risks; to define its effects on items, typology and amounts of damage; to develop mitigation methodologies. This requires more investments and a serious plan to solve recognised problems.

Although in the two decades of the second millennium new approaches spread among Portuguese institutions allowing a better control of the situation, the implementation of preventive conservation strategies continues to be unsatisfactory. Also, no evidence of real collaboration between research groups and heritage institutions has resulted in improvements to the present situation where pest problems tend to subsist and there is no evidence of measures being taken on a regular basis or the development of a true strategy for the future. The increase shift of managers from professionals of the area to communication and economic backgrounds and politicians, with little preservation policies culture, raises new concerns. The tendency to invest more on initiatives with public visibility as opposed to preservation policies needs to change if current societies really intent to pass on to next generations the cultural heritage richness, values and identity. The presented Portuguese case study emphasizes that not only it is urgent to increase the awareness of institutional and political decision makers about preventive conservation but also to find new and sustainable ways to maintain our cultural heritage. This requires more investigation and a transversal dialogue between all partners: cultural heritage professionals (conservators, librarians, archivists and curators), managers, politicians and final users. The whole community needs to become more aware of the unsolved problems but also of the ones to be faced in the near future. Decisions such as the introduction of on-site generated nitrogen into the biocidal products regulation EU 528/2012 represents a setback. Thus, we argue that it is mandatory that heritage professionals are able, once again, to raise their voices against ill-informed managers or politicians and increase the awareness for sustainable management and reinforce the need for more research in the field. Only then will it be possible to recognise and honour those professionals who for over a century have defended preventive conservation and were well aware of its merits.

\section{Acknowledgements}

This research was funded by the Foundation for Science and Technology, from Portugal (FCT) through the project CleanART - Innovative Methodology to Clean Fungal Stains from Paper Documents and Artworks (PTDC/EPH-PAT/0224/2014). Also, this work had the support of the research Units funding: Associated Laboratory for Green ChemistryLAQV which is financed by national funds from FCT/MCTES (UID/ QUI/50006/2019) and co-financed by the ERDF under the PT2O20 Partnership Agreement (POCI-01-0145-FEDER-007265); and the education programme of Conservation and Restoration Department from the Faculty of Science and Technology from Universidade NOVA de Lisboa. Ana Catarina Pinheiro is under a researcher contract with the HERCULES Laboratory, Évora University (CEECIND/02598/2017).

\section{REFERENCES}

1. Pinniger, D., Insect Pests In Museums, 3rd ed., Archetype Publications Limited, London (1994).

2. Karlsson, S.; Albertsson, A., 'Biodegradable polymers and environmental interaction', Polymer Engineering and Science 38(8) (2004) 1251-1253, https://doi.org/10.1002/pen.10294.

3. Guillitte, O., 'Bioreceptivity - a new concept for building ecology studies', Science of the Total Environment 167 (1995) 215220, https://doi.org/10.1016/0048-9697(95)04582-L.

4. Sequeira, S.; Cabrita, E.; Macedo, F., 'Antifungals on paper conservation: An overview', International Biodeterioration \& Biodegradation 74 (2012) 67-86, https://doi.org/10.1016/j. ibiod.2012.07.011.

5. Allsopp, D.; Seal, K.; Gaylarde, C., Introduction to Biodeterioration, 2nd ed., Press Syndicate of the University of Cambridge, Cambridge, England (2004).

6. Valdés-Pérez, O.; Borrego-Alonso, S.; Vivar-González, I.; Anaya-Villalpanda, M.; Molina-Veloso, A., 'Actividade antifúngica del aceite esencial de clavo de olor en el control del biodeterioro fúngico de documentos', Revista CENIC Ciencias Biológicas 47(2) (2016) 78-85.

7. Pool, M.; Odegaard, N.; Huber, M., 'Identifying the pesticides: pesticide names, classification and history of use', in Old Poisons, New Problems: A Museum Resource for Managing Contaminated Cultural Material, ed. N. Odegaard and A. S. Alyce, Altamira Press, Walnut Creek (2005) 5-31. 
8. Mallo, A.; Nitiu, D.; Elíades, L.; Saparrat, M., 'Fungal degradation of cellulosic materials used as support for Cultural Heritage', International Journal of Conservation Science 8(4) (2017) 619-632, http://ijcs.ro/public/IJCS-17-59_Mallo.pdf.

9. Pasquariello, G.; Valentin, P.; Maggi, O.; Persiani, A., 'Biodeterioration processes in relation to cultural heritage materials', in Plant Biology for Cultural Heritage: Biodeterioration and Conservation, ed. G. Caneva, M.P. Nugari and M. P. Salvadori, Getty Conservation Institute, Los Angeles (2009) 108-113.

10. Gallo, F.; Pasquariello, G., 'Biological investigation on sizings for permanent papers', Restaurator 19 (1998) 61-84, https://doi. org/10.1515/rest.1998.19.2.61.

11. Valentin, N., 'Microbial contamination in archives and museums: health hazards and preventive strategies using air ventilation systems', in Proceedings of the Experts' Roundtable on Sustainable Climate Management Strategies, Tenerife (2007) 1-26.

12. Choi, S., 'Foxing on paper: A literature review', Journal of the American Institute for Conservation 46(2) (2007) 137-152, https:// doi.org/10.1179/019713607806112378.

13. Arai, H., 'Foxing caused by Fungi: twenty-five years of study', International Biodeterioration \& Biodegradation 46(3) (2000) 181188, https://doi.org/10.1016/S0964-8305(00)00063-9.

14. Bonnardot, A., Essai Sur L'art de Restaurer les Estampes et les Livres, 2nd ed., Castel, Paris (1858), https://archive.org/details/ essaisurlartdereoobonn.

15. Macedo, M., Restauração de Quadros e Gravuras, ed. David Corazzi, Lisboa (1885).

16. Ribeiro, J. P., Observações Historicas e Criticas para Servirem de Memorias ao Systema da Diplomatica Portugueza, Parte 1, Typografia da Academia Real das Sciencias, Lisboa (1798).

17. Constantin, L-A., Bibliothéconomie ou, Nouveau Manuel Complet Pour L'arrangement, la Conservation et L'administration des Bibliothèques, Librarie Encyclopédique de Roret, Paris (1841).

18. Casanova, C., 'A century of paper conservation and the development of the professional status of the conservator', in Proceedings of the 16th Triennial Conference ICOM-CC, Lisboa (2011) 1-8.

19. Casanova, C. 'What do we need? Education, ethics, new values or a different perception for the profession!', in New Approaches to Book and Paper Conservation-Restoration, ed. P. Engel, R. Larsen, I. Kecskeméti, V. Berger, Horn/Wien (2011) 45-66.

20. Lambert, S., 'The early history of preventive conservation in Great Britain and the United States (1850-1950)', CeROArt 9 (2014), https://journals.openedition.org/ceroart/3765.

21. Marberly, J., The Print Collector: an Introduction to the Knowledge Necessary for Forming a Collection of Ancient Prints: Remarks on the Ancient and Modern Practice of the Art and A catalogue Raisonné of Books, Landers \& Otley, London (1844).

22. Poulsson, T. G., Retouching of Art on Paper, Archetype, London (2008).

23. Clarke, B., 'Searching for evidence of 19th century print restoration', in Past practice-future prospects, ed. A. Oddy and S. Smith, British Museum Press, London (2001) 49-55.

24. Ris-Paquot, O. E., L'art de Restaurer les Tableaux Anciens et Modernes Ainsi que les Gravures, Chez l'Auteur, Amiens (1873).

25. Ris-Paquot, O. E., Guide Pratique du Restaurateur-Amateur de
Tableaux, Gravures, Dessins, Pastels, Miniatures, Henri Laurens, Éditeur, Paris (1890).

26. Gunn, M. J., Print Restoration and Picture Cleaning: an Illustrated Practical Guide to the Restoration of all Kinds of Prints, L. Upcott Gill, London (1911).

27. Beaufort, T. R., Pictures $\&$ How to Clean Them. To Which are Added Notes on Things Useful in Restoration Work, John Lane, London (1926).

28. Lucanus, Fr. G. H., Die Praxis des Restaurators: vollständige Anleitung zur Erhaltung, Reinigung und Wiederherstellung von Gemälden, Aquarellen, Kupferstichen, etc, 5th ed., ed. Hans Böhm, Zentralantiquariat der DDR, Leipzig (1982).

29. Morgana, M., Restauro dei Libri Antichi, Ulrico Hoepli, Milano (1932).

30. Schweidler, M., The restoration of engravings, drawings, books, and other works on paper, ed. Roy Perkinson, Getty Conservation Institute, Los Angeles (2006).

31. Plenderleith, H. J., The Conservation Of Prints, Drawings And Manuscripts, Published for the Museums Association, Oxford University Press, London (1937).

32. Flieder, F., La Conservation De Documents Graphiques: Recherches Expérimentales, Eyrolles, Paris (1969).

33. Jenkinson, H., A Manual on Archive Administration, Milford, London (1922).

34. Maire, A., Manuel Pratique du Bibliothècare, Alphonse Picard et Fils Éditeurs, Paris (1896).

35. Casanova, C., 'De artífice a cientista. Evolução da conservação e do estatuto profissional do conservador-restaurador de documentos gráficos no AHU (1926-2006)', PhD dissertation, Departamento Conservação e Restauro, Universidade NOVA de Lisboa, Lisboa (2012), https://run.unl.pt/handle/10362/8777.

36. Saraiva, F. M. J., 'Dois objectos se devem ter prezentes, quando se trata de qualquer cartório, $1^{\circ} \mathrm{A}$ conservação dos títulos, $2^{\circ} \mathrm{A}$ sua ordem e arranjamento', Arquivo de Bibliografia Portuguesa 2 (12) (1957) 219-220.

37. Azevedo, P., 'Meios de defesa dos archivos', O Arqueólogo Português, Série 1, 13 (1908) 6-10.

38. Noronha, J. F., 'Relatorio àcerca da Bibliotheca Nacional e mais estabelecimentos annexos' dirigido ao Exm. ${ }^{\circ} \mathrm{Sr}$. Ministro e Secretario d'Estado dos Negocios do Reino no $1^{\circ}$ de janeiro de 1844, Vol. 1, Typographia Lusitana, Lisboa (1844), http://purl.pt/242.

39. Bandeira, A. M. L., Pergaminho e Papel em Portugal: Tradição e Conservação, Associação da Indústria Papeleira / Associação Portuguesa de Bibliotecários, Arquivistas e Documentalistas, Lisboa (1995).

40. Ferrão, A., Os Arquivos E As Bibliotecas Em Portugal, Imprensa da Universidade, Coimbra (1920).

41. Moniz, J., Summario das Lições de Bibliologia: Curso de Bibliothecario-Archivista, 2nd ed., Inspecção Geral das Bibliothecas e Archivos Públicos, Coimbra (1900).

42. Sampaio, E. J. F., Contribuição para o Estudo da Entomofauna do Livro em Portugal: Situação Sanitária das Bibliotecas e Arquivos, Inspecção Superior das Bibliotecas e Arquivos, Lisboa (1960).

43. Sampaio, E. J. F., Pais Morais, J., Determinação da Taxa de Incidência do Ataque de Bibliófagos, Inspecção Superior das Bibliotecas e Arquivos, Lisboa (1962).

44. Alves, M. L.; Esteves, L., 'Levantamento do estado sanitário das bibliotecas e arquivos', in $2^{\circ}$ Congresso Nacional de 
Bibliotecários, Arquivistas e Documentalistas. A integração Europeia: Um desafio à informação, Livraria Minerva, Coimbra (1987) 349-420.

45. Casanova, C., 'A conservação do património arquivístico', in Actas do $3^{\circ}$ Congresso de Bibliotecários, Arquivistas e Documentalistas, $1^{\circ}$ vol., Lisboa (1990) 85-89.

46. Decreto-lei No 936 , Diário do Govêrno - N. ${ }^{\circ} 183 / 1914$, SÉRIE I DE 1914-10-08.

47. Worthing, C. R.; Hance, R. J., The Pesticide Manual, A World Compendium, 9th ed., British Crop Protection Council, Farnham (1991).

48. Santos, S. C., 'O arquivo do Hospital de S. José', Anais das Bibliotecas e Arquivos 1(1) (1920) 129-135, http://purl.pt/258/2/ bad-1510-v_01/bad-1510-v_01_item2/P240.html.

49. Baynes-Cope, A. D., 'The choice of biocides for library and archival material', in Biodeterioration of Materials, vol. 2, Applied Science Publications Ltd., New York (1971) 381-383.

50. Gallo, F., 'Aspetti della lotta preventiva e curativa contro i microrganismi dannosi al materiale bibliografico e archivistico', Bolletino dell'Istituto di patologia del libro $\mathbf{2 2}$ (1963) 29-66.

51. Valentin, N.; García Ortega, R., 'El biodeterioro en el museo', Arbor 164 (1999) 85-107.

52. Zervos, S.; Alexopoulou, I., 'Paper conservation methods: A literature review', Cellulose 5 (2015) 1-60, https://doi. org/10.1007/s10570-015-0699-7.

53. Sampaio, A. F. de, Como Devo Formar A Minha Biblioteca: Ensaio, Sá da Costa, Lisboa (1938).

54. Craig, R., 'Alternative approaches to the treatment of mould biodeterioration - an international problem', Paper Conservator 10 (1986) 27-30, https://doi.org/10.1080/03094227.1986.9638528.

55. Flieder, F., 'Action des différents produits fongicides et insecticides, utilisés en conservation sur la résistance physico-chimique des papiers', in 5th Joint Meeting of The ICOM Committee for Museum Laboratories and of the Sub-Committee for the Care of Paintings, ICOM, New York (1965) 1-46.

56. Haines, J. H.; Kohler, S.A., 'An evaluation of ortho-phenyl phenol as a fungicidal fumigant for archives and libraries', Journal of the American Institute for Conservation 25 (1986) 49-55.

57. Gustafson, R. A.; Modaresi, I. R.; Hampton, G. V.; Chepesiuk, R. J.; Kelley, G. A., 'Fungicidal efficacy of selected chemicals in thymol cabinets', Journal of American Institute for Conservation 29 (1990) 153-168, https://doi.org/10.2307/3179580.

58. Strassberg, R., 'The use of fumigants in archival repositories', The American Archivist 4 (1978) 25-26, https://doi.org/10.17723/ aarc.41.1.n53p501435534314.

59. Daniels, V., Boyd, B., 'The yellowing of thymol in the display of prints', Studies in Conservation 31 (1986) 156-158, https://doi. org/10.2307/1506246.

60. Isbell, L. H., 'The effects of thymol on paper, pigments, and media', Abbey Newsletter 21 (1997) 39-43.

61. Karpouhtsis, I.; Pardali, E.; Feggou, E.; Kokkini, S.; Scouras, Z. G.; Mavragani Tsipidou, P., 'Insecticidal and genotoxic activities of oregano essential oils', Journal of Agricultural and Food Chemistry 46 (1998) 1111-1115, https://doi.org/10.1021/ jf9708220.

62. Hough, W. A. M., 'The preservation of museum specimens from insects and the effects of dampness', in Annual report of the board of regents of the Smithsonian Institution for the year ending June 30, 1887, Pt.2, Government Printing Office, Washington D.C. (1889) 549-558.

63. Carson, R., Silent Spring, 1st ed., Houghton Mifflin Company, Boston (1962).

64. Pinniger, D.; Harmon, J., 'Pest management, preservation and control', in Care and conservation of Natural History Collections, ed. D. Carter, A. Walker, Butterworth Heinemann, Oxford, (1999) 152-176.

65. D'Amato, C.; Torres, J.; Malm, O., 'DDT (dicloro difenil tricloroetano): toxicidade e contaminação ambiental - uma revisão', Química Nova 25(6a) (2002) 995-1002, http://dx.doi. org/10.1590/S0100-40422002000600017.

66. Mabuchi, H.; Sano, C., 'Residual bromine on materials fumigated with methyl bromide', Science for Conservation 43 (2004) 43-46.

67. Kigawa, R.; Strang, T.; Hayakawa, N.;Yoshida, N.; Kimura, H.; Young, G., 'Investigation of Effects of Fumigants on Proteinaceous Components of Museum Objects (Muscle, Animal Glue and Silk) in Comparison with Other Nonchemical Pest Eradicating Measures', Studies in Conservation 56(3) (2011) 191-215, https://doi.org/10.1179/20470581 IX13110713013272.

68. Ballard, M. W.; Baer, N. S., 'Ethylene Oxide Fumigation: Results and Risk Assessment', Restaurator 7 (1986) 143-168, https://doi.org/10.1515/rest.1986.7.4.143.

69. Valentin, N., 'Biodeterioration of library materials disinfection methods and new alternatives', The Paper Conservator 10 (1986) 40-45, https://doi.org/10.1080/03094227.1 986.9638530.

70. Hey, M.; Petherbridge, G., 'Paper conservation processes hazardous to health', The Paper Conservator 5-6 (1980) 5-13, https://doi.org/10.1080/03094227.1980.9638657.

71. Tateo, F.; Bononi, M., 'Determination of ethylene chlorohydrin as marker of spices fumigation with ethylene oxide', Journal of Food Composition and Analysis 19 (2006) 83-87, https://doi. org/10.1016/j.jfca.2004.12.003.

72. Paulus, W. (Ed.), Directory of Microbicides for the Protection of Materials - A Handbook, Kluwer Academic Publishers, Dordrecht (2004).

73. Triolo, L.; Di Trapani, R.; Santucci, L., 'Resistenza e stabilità della carta:VII. Trattamento con composti fungicidi', Bollettino dell'Istituto di Patologia del Libro 27 (1968) 207-224.

74. Nittérus, M., 'Ethanol as fungal sanitizer in paper conservation', Restaurator 21 (2000) 101-115, https://doi. org/10.1515/REST.2000.101.

75. Bacílková, B., 'Study on the effect of butanol vapours and other alcohols on fungi', Restaurator 27 (2006) 186-199, https:// doi.org/10.1515/REST.2006.186.

76. Sequeira, S.; Phillips, A. J. L.; Cabrita, E. J.; Macedo, M. F., 'Ethanol as an antifungal treatment for paper: short-term and long-term effects', Studies in Conservation 62(1) (2017) 33-42, https://doi.org/10.1080/00393630.2015.1137428.

77. Pinniger, D.; Winsor, P., Integrated Pest Management, A Guide For Museums, Libraries And Archives, Museums, libraries and archives Council, London (2004).

78. Sonoda, N., 'Museum Environment Control for Sustainable Collection Management', in Asian Museums and Museology 2014: International Workshop on Asian Museums and 
Museology in Thailand (Senri Ethnological Reports 129), eds. N. Sonoda., K.Hirai, J.Incherdchai (2015) 27-35, http://doi. org/10.15021/00000798.

79. 'CSN EN 16790: Conservation of cultural heritage - Integrated pest management (IPM) for protection of cultural heritage', in European Standards, BSI (2016), https://www.en-standard.eu/ csn-en-16790-conservation-of-cultural-heritage-integratedpest-management-ipm-for-protection-of-cultural-heritage/.

80. Strang, T., 'Studies in Pest Control for Cultural Property', PhD dissertation, Department of Conservation, University of Gothenburg, Gothenburg (2012), http://hdl.handle. net $/ 2077 / 31500$.

81. Hocking, A. D., 'Responses of fungi to modified atmospheres', in Fumigation and Controlled Atmosphere Storage of Grain, ACIAR Proceedings No. 25, eds. B.R. Champ, E. Highley and H.J. Banks, Australian Centre for International Agricultural Research, Canberra (1989) 70-82.

82. Valentin, N.; Lidstrom, M.; Preusser, F., 'Microbial control by low oxygen and low relative humidity environment', Studies in Conservation 35 (1990) 222-230, https://doi.org/10.1179/ sic.1990.35.4.222.

83. Gilberg M., 'The Effects of Low Oxygen Atmospheres on Museum Pests', Studies in Conservation 36(2) (1991) 93-98, https://doi.org/10.2307/1506333.

84. Hanlon, G.; Daniel, V.; Ravenel, N.; Maekawa, S., 'Dynamic system for nitrogen anoxia of large museum objects: a pest eradication case study', in 2nd International Conference on Biodeterioration of Cultural Property, S.I.:the Organizing commitee of ICBCP-2, Yokohama (1992).

85. Xavier-Rowe, A.; Lauder, D., 'Ten years of integrated pest management at English Heritage', in Integrated Pest Management for Collections. Proceedings of 2011: A Pest Odyssey, 10 Years Later, eds. P. Winsor, D. Pinniger, L. Bacon, B. Child, K. Harris, D. Lauder, J. Phippard \& A. Xavier-Rowe, English Heritage, Swindon (2011) 10- 15.

86. Brimblecombe, P.; Lankester, P., 'Long-term changes in climate and insect damage in historic houses', Studies in Conservation 58(1) (2013) 13-22, https://doi.org/10.1179/20470584 $12 Y .0000000051$.

87. Nobre, T.; Nunes, L., 'Preliminary Assessment of the Termite Distribution in Portugal', Silva Lusitana 9(2) (2001) 217-224, http://www.scielo.mec.pt/pdf/slu/v9n2/9n2a09.pdf.
88. Mendes, L. F., 'Note sur les Zygentoma (Insecta: Apterygota) de l'Europe et du bassin mediterranéen', Arquivos do Museu Bocage (2 ${ }^{a}$ Sér.) 7(14) (1980) 215-260.

89. Regulation (EU) No 528/2012 of the European Parliament and of the Council of 22 May 2012 concerning the making available on the market and use of biocidal products, https://eur-lex.europa.eu/ LexUriServ/LexUriServ.do?uri=OJ:L:2012:167:0001:0123:EN:P DF (accessed 2019-10-10).

90. ICOM-ICOMOS Joint Statement, https://www.icomos.org/images/DOCUMENTS/ Secretariat/2019/ICOM-ICOMOS_Statement/ICOMICOMOS_UE_N\%C2\%BA_528_2012_Statement.pdf (accessed 2019-10-10).

91. Dawson, J., 'The effects of insecticides on museum artefacts and materials', in A guide to museum pest control, ed. L.A Zycherman, \& J. R. Schrock, Assoc. of Syst. Collections, Washington D. C. (1988) 135-150.

92. International Chemical Safety Cards (ICSCs), 'International Labour Organization', https://www.ilo.org/dyn/icsc/showcard. listCards3?p_lang=en (accessed 2019-09-28)

93. Hickin, N., Bookworms. The Insect Pests of Books, Sheppard Press Limited, London (1985).

94. VanDyk, J., BugGuide, Department of Entomology, Iowa State University Ames (2003-2020), https://bugguide.net/ termsofuse (accessed 2020-03-25).

RECEIVED: 2020.1 .23

REVISED: 2020.4 .28

ACCEPTED: 2020.5 .28

ONLINE: 2020.8 .17

\section{(c) (1) (3)}

This work is licensed under the Creative Commons Attribution-NonCommercial-NoDerivatives 4.0 International License. To view a copy of this license, visit http://creativecommons.org/licenses/by-nc-nd/4.o/deed.en. 